\title{
Unplayed Melodies
}


The publisher gratefully acknowledges the generous contribution to this book provided by the Music Endowment Fund of the University of California Press Associates and by Brown University. 


\section{Unplayed Melodies}

Javanese Gamelan and the Genesis of Music Theory

MARC PERLMAN

University of California Press

BERKELEY LOS ANGELES LONDON 
Unless otherwise noted in captions, all music examples are by the author.

University of California Press

Berkeley and Los Angeles, California

University of California Press, Ltd.

London, England

(C) 2004 by the Regents of the University of California

Library of Congress Cataloging-in-Publication Data

Perlman, Marc.

Unplayed melodies : Javanese gamelan and the genesis of music theory / Marc Perlman.

p. $\mathrm{cm}$.

Includes bibliographical references (p. ) and index.

ISBN 0-520-23956-3 (cloth : alk. paper)

1. Music-Indonesia-Java-History and criticism. 2. Gamelan music - Indonesia—Java-History and criticism. 3. Melody.

I. Title.

ML345.J3 P46 2004

781.2'4'095982-dc21

2003006432

Manufactured in the United States of America

$\begin{array}{llllllllll}13 & 12 & 11 & 10 & 09 & 08 & 07 & 06 & 05 & 04\end{array}$

$\begin{array}{llllllllll}10 & 9 & 8 & 7 & 6 & 5 & 4 & 3 & 2 & 1\end{array}$

The paper used in this publication meets the minimum requirements of ANSI/NIsO Z39.48-1992 (R 1997) (Permanence of Paper).@ 
To my teachers, whose thoughts inspired this book:

Suhardi (R. L. Wignya Bremara, 1937-2000)

Sumarsam

Supanggah 
This page intentionally left blank 